\title{
Stack Capacity in Medical and Science Libraries
}

\author{
Justine Roberts
}

Academic medical and science libraries provide informational support for patient care and for research leading to clinical and technological advancement and the growth of basic biological and physical knowledge. Despite such high intention, our success or failure often hangs on mundane operational detail, whether we are working with automated or manual systems. Accurate estimation of stack capacity is one such detail, important both to successful facilities planning and to project planning and design. For space planning, Metcalf noted in 1965 that "there is disagreement in regard to how many volumes can be stored in a given amount of space." He rejected most previous work in this area and stated flatly, "formulas for capacity are dangerous and none ... are completely satisfactory. ${ }^{\prime 1}$ Nonetheless, he carefully tabulated linear space requirements for different kinds of "books," adapting a table "in common use by stack manufacturers [and] used by Wheeler and Githens [in their 1941 work on public library buildings $\left.{ }^{2}\right] .^{\prime \prime 3}$ Metcalf labeled his specifications clearly: "Volumes per foot of shelf ... . when shelves are filled solidly." His figures, if not his advice, have been repeated and reflected regularly in scores of planning guides that postdate his work, though they sometimes are presented ambiguously with regard to their use as planning optima vs. their use as capacity measures. ${ }^{4-1}$

Metcalf and most of his later communicants differentiate "medical books," "science and technology books," and "bound periodicals" from the common average. Metcalf's statement is:

... When Shelves are Filled Solidly

$\begin{array}{lcc}\text { Volumes } & \begin{array}{c}\text { Volumes } \\ \text { single-faced } \\ \text { per foot } \\ \text { of shelf }\end{array} & \begin{array}{c}7 \text {-shelf) } \\ \text { section }\end{array} \\ \begin{array}{l}\text { Technical and sci- } \\ \text { entific }\end{array} & 6 & 126 \\ \text { Medical } & 5 & 105 \\ \text { Bound periodicals } & 5 & 105\end{array}$

These figures are repeated by Zachert in advice to pharmacy librarians, ${ }^{11}$ and further developed there to foster space planning calculations:

Calculations ... based on shelves no more than $2 / 3$ ds full

$\begin{array}{ccc}\text { Volumes } & \begin{array}{c}\text { Volumes } \\ \text { per foot } \\ \text { of shelf }\end{array} & \begin{array}{c}\text { single-faced } \\ \text { per (7-shelf) } \\ \text { section }\end{array} \\ \begin{array}{ccc}\text { Technical and sci- } \\ \text { entific }\end{array} & {[4]^{*}} & 84 \\ \text { Periodical volumes } & {[3]^{*}} & 60 \\ \text { (*-computed) } & & \end{array}$

Government advice to medical school library planners reduces Metcalf's 105 volumes per single-faced section to $100 \mathrm{vol}$ umes, closely equivalent at 4.76 volumes per linear foot (VLF). ${ }^{12}$ The third edition of the Medical Library Association's Handbook states flatly that stack capacity is 4.5 to 5 volumes per foot of shelf, but is unclear as to whether this is a planning optimum or a statement of maximum capacity. ${ }^{13}$

Current experience at the University of California at San Francisco (UCSF) had shown that the "standard" VLF figures could be as much as 100 percent too low in providing reliable estimates for monographs and serials stacks. During 1982, samples of several hundred books at the University of North Carolina at Chapel Hill Health Sciences Library, and of several thousand volumes in the Science Sec-

Justine Roberts is head, Library Systems Office, University of California, San Francisco 94143. The author was assisted by Alison Bunting, Jacqueline Doyle, Beverlee French, Winifred Kistler, Joyce Loepprich, Rebecca Martin, and Faith Meakin. 
tion at the University of Guelph Library, yielded shelf capacity width estimates up to twice the standard. ${ }^{14,15}$ The standard figures have been repeatedly cited with little change or verification for at least forty years, and some of the work on which they are based goes back nearly fifty years. ${ }^{16}$ It is hard to believe, for instance, that the size of serial binding units has remained stable during all this time as, first, individual journal titles have fattenedwith more articles per issue-and then split or changed frequency as specialization and editorial management considerations intervened. The dramatic increase in medical specialization also must have had some effect on average monograph size. For example, where there used to be only a 21/2-inch-thick Gray's Anatomy, there is now likely to be a Gray's plus a series of considerably thinner regional topologies. Similarly, the enlarged interdisciplinary scope of many academic health sciences library collections is another notable trend not reflected in available data.

Metcalf and others warn, with obvious good reason, against facilities planning that overestimates stack capacity, but they fail to offer adequate or current evidence to support the figures that are offered. At the same time, repetitive and sparsely reported local measurement projects continue to be undertaken in the absence of reliable current stack capacity figures for local planning.

These various uncertainties and the continuous pressure of planning work prompted the cooperative development of a stack capacity study by librarians at five health sciences libraries and two science libraries at the University of California (UC) (see table 1). Funding support and librarians' time were made available through a university-supported research program initiated by the systemwide Librarians Association. The ecumenical effect of the stack capacity problem is indicated by the investigators' working titles: they were branch heads in two cases, from public services at three libraries, and from technical services and systems at the remaining two.

The project was initially undertaken as the first step of a larger study, with the intent of testing data collection and sampling methods at each library. For this reason, only small samples, consisting of one hundred serials shelves and one hundred monograph shelves, were measured at each location, and no attempt was made to predetermine serials/monograph weighting factors, or to set final statistical requirements. The autonomy, varying scopes, widely varying sizes, and very different chronologies of the libraries were expected to result in very disparate observational environments and statistics. The former, but not the latter, proved to be true. The pilot study results are therefore reported here with the expectation that they may be useful in other academic science libraries.

\section{METHODOLOGY}

Participants agreed on a common set of material definitions and exclusions and marked out qualifying ranges on existing or newly drawn stack maps. These were sent to UCSF where each map's stack sections were sequentially numbered. Sections holding over- or undersized books, rare or reference books, and/or unboxed,

TABLE 1

UNIVERSITY OF CALIFORNIA-SIZE OF COLLECTIONS

\begin{tabular}{lcc}
\hline Libraries & $\begin{array}{c}\text { Total } \\
\text { Bound Volumes }\end{array}$ & $\begin{array}{c}\text { Serials } \\
\text { Currently Received }\end{array}$ \\
\hline Berkeley-Biology Library & 202,579 & 3,981 \\
Davis-Health Sciences Library & 157,691 & 4,819 \\
Irvine-Biomedical Library & 109,612 & 1,596 \\
Los Angeles-Biomedical Library & 388,366 & 7,068 \\
San Diego-Biomedical Library & 144,367 & 3,330 \\
San Diego-Science \& Engineering Library & 117,240 & 2,062 \\
San Francisco-Health Sciences Library & 489,793 & 3,909 \\
\hline
\end{tabular}

Source: University of California Library Statistics July 1982. Office of the Assistant Vice President-Library Plans and Policies, University of California Systemwide Administration [1982]. 11p. 
single issues of serials, were generally excluded. The remaining qualified shelves, distributed through some ten thousand stack sections, constituted the population from which one random sample each of monograph shelves and of serials shelves was drawn for each library.

As expected, serials and monographs were shown on the maps to be separately shelved at each of the five health sciences libraries and intermixed at the two science libraries. However, we found that at the University of California at Berkeley Biology Library (UCB) nearly 27 percent of the stack shelves were in mixed sections, but that this was true for less than 4 percent of University of California at San Diego (UCSD) Science \& Engineering Library shelves. In both cases, one half of these mixed sections were arbitrarily assigned to the serials population and one half to monographs.

The SAS Statistical Package (Version 79.5) PLAN procedure was used to select the fourteen random samples of sections and shelves from the seven libraries and to create the work sheets that would be used for data collection. It was also necessary to know the maximum number of shelves that would be found in any section so that a ("randomly" selected) shelf could be identified within each section. Inspection of the maps showed that slightly over one fourth of the monograph sections and 15 percent of the serials sections were other than the normal 7-shelf sections. The SAS procedure could not sort its random selections into an order corresponding to the numerically sequenced stack sections. The computer output therefore was saved into and sorted from separate online files, and the resulting work sheets were printed from these files rather than directly from the SAS program.

\section{Data Collection}

For the two hundred selected sections for each library, data collectors recorded two numbers for each shelf: (1) the number of volumes on the shelf, and (2) the width in centimeters of the shelf space occupied by these volumes. No troublesome data collection problems were reported by the participants, with one exception: the draft workbook instructions had assumed a uniform width for filled standard threefoot shelves. Midway through the project we discovered that the filing capacity of standard three-foot stack shelves in the seven libraries ranged at least from 87 to $90 \mathrm{~cm}$ (34.25-35.4 inches), with four libraries reporting 88.5 and two reporting $90 \mathrm{~cm}$ filing widths.

Returned work sheets were sent for keying to a commercial data entry agency that keyed and verified the fourteen hundred observations from clean, legible copy at a cost of approximately six cents per observation. Times reported for the data collection ranged from 8 to 15 hours (2.4-4.5 minutes per measured shelf). This included the time required to locate and identify selected sections and to select alternate sections when the sample selection was disqualified or invalid for any reason.

\section{Overall Results}

\section{RESULTS}

The stack populations in this study consisted of approximately 68,708 shelves in seven libraries, distributed as shown in table 2 . The number of books and their occupied shelf width were counted and measured respectively for a random sample of one hundred serials stacks shelves and one hundred monograph stacks shelves at each library. All measures represent solidly packed shelves. For all seven libraries, the combined serials stacks measurements $(n=700)$ averaged 7.6 (VLF), with a range of 1.6 volumes between the lowest average, 7 VLF at UCSD-B, and highest average, 8.6 VLF at UCLA. Both science libraries were within this range, averaging 7.3 VLF each (see table 3 ).

The combined stack monograph measurements $(n=700)$ averaged 11.4 VLF, with a range of .6 volume between the lowest health sciences library average, 10.9 at UCI, and highest health sciences figure 11.5 at UCSF. The UCSD Science \& Engineering Library was outside this range, at 11.9 VLF; UCB was within it, at 11.5 VLF.

The 95 percent confidence interval for the combined 7-library serials and monograph means was \pm .2 , that is, if similar 
TABLE 2

UNIVERSITY OF CALIFORNIA STUDY POPULATION

\begin{tabular}{lrccr}
\hline \hline Libraries & $\begin{array}{c}\text { Serials } \\
\text { Shelves }\end{array}$ & $\begin{array}{c}\text { Monograph } \\
\text { Shelves }\end{array}$ & $\begin{array}{c}\text { Mixed } \\
\text { Shelves }\end{array}$ & $\begin{array}{c}\text { Total } \\
\text { Shelves }\end{array}$ \\
\hline Berkeley-Biology Library & 4,358 & 1,159 & 2,016 & 7,533 \\
Davis-Health Sciences Library & 8,727 & 2,868 & - & 11,595 \\
Irvine-Biomedical Library & 3,062 & 1,023 & - & 4,085 \\
Los Angeles-Biomedical Library & 12,407 & 5,631 & - & 18,038 \\
San Diego-Biomedical Library & 6,196 & 2,965 & - & 9,161 \\
San Diego-Science \& Engineering Library & 3,542 & 1,249 & 188 & 4,979 \\
San Francisco-Health Sciences Library & 9,037 & 4,280 & - & 13,317 \\
Total All Libraries & 47,329 & 19,175 & 2,204 & 68,708 \\
Percent of Total & $(68.9)$ & $(27.9)$ & $(3.2)$ & $(100.0)$ \\
\hline
\end{tabular}

TABLE 3

SAMPLE SHELF MEASUREMENTS: VOLUME WIDTHS-ALL LIBRARIES

\begin{tabular}{lccccc}
\hline $\begin{array}{l}\text { Format } \\
(n)\end{array}$ & $\begin{array}{c}\text { Mean Volumes } \\
\text { per Foot of Shelf } \\
\text { (When Shelves Are } \\
\text { Filled Solidly) }\end{array}$ & $\begin{array}{c}\text { Standard } \\
\text { Deviation }\end{array}$ & $\begin{array}{c}95 \text { Percent } \\
\text { Confidence } \\
\text { Limits }\end{array}$ & $\begin{array}{c}\text { Range of Volumes } \\
\text { per Foot of } \\
\text { (filled) Shelf }\end{array}$ & $\begin{array}{c}\text { Average } \\
\text { Inches per } \\
\text { Volume* }\end{array}$ \\
\hline $\begin{array}{l}\text { Serials } \\
(700)\end{array}$ & 7.6 & 2.4 & \pm .2 & $2.8-19.6$ & 1.60 \\
$\begin{array}{l}\text { Monographs } \\
(700)\end{array}$ & 11.4 & 2.9 & \pm .2 & $3.1-31.9$ & 1.06 \\
\hline
\end{tabular}

*Using the "unbiased" average (see text).

samples were repeated, the averages found ninety-five out of one hundred times would be expected to be between 7.4 and 7.8 VLF for serials, and between 11.2 and 11.6 VLF for monographs.

All figures shown in tables 3 and 4 are computed on the basis of solidly filled shelves, and therefore do NOT represent working stack capacity or planning optimums, discussed in the next section. It is also important to note that the sampling method used for these tests results in an equal but therefore nonproportional representation of serials and monograph shelves in the total sample. Thus monographs are overrepresented in the overall mixed format results shown in table 4: the average 9.5 VLF shown for the total sample necessarily understates the average volume thickness at the participating libraries. A weighted mixed format average can be computed for the combined samples by using the relative serials/mono- graph shelf proportion (from table 2) as a weighting element. ${ }^{*}$ This yields a computed average of 8.7 VLF for the entire sample. Serials volumes can be seen on the average to be one and one half times the width of monograph volumes, an important planning consideration for science and health sciences libraries, where serials are dominant. The data show small differences, at least for these samples, between average widths in the health sciences libraries and science libraries. Health sciences serials volumes are found to be slightly thinner than science serials volumes, and the opposite true for monographs: science monograph volumes are slightly thinner than their health sciences library counterparts.

Slightly different figures resulted from two different methods of calculating an "average" VLF. The first method, used for most of the results reported here, takes the results of each VLF calculation for each

*There are roughly 2.5 serials shelves for each monograph shelf in the serials/monograph stack population. If this weight is used to increase the contribution of serials measurements to the computed mean, then the number of serials observations increases to 1750 and total observations increase to 2450. The weighting equation is taken from R. P. Runyon and A. Haber, Fundamentals of Behavioral Statistics, 4th ed. (Reading, Mass.: Addison-Wesley, 1980), p.78. 
TABLE 4

SAMPLE SHELF MEASUREMENTS: VOLUME WIDTHSCOMBINED MONOGRAPHS AND SERIALS*-BY TYPE OF LIBRARY

\begin{tabular}{lccc}
\hline \hline $\begin{array}{l}\text { Libraries } \\
(n)\end{array}$ & $\begin{array}{c}\text { Mean Volumes per Foot } \\
\text { of Shelf When Shelves } \\
\text { Are Filled Solidly. } \\
\text { (Weighted Mean)* }\end{array}$ & $\begin{array}{c}\text { Standard } \\
\text { Deviation }\end{array}$ & $\begin{array}{c}\text { Range of Volumes } \\
\text { per Foot of } \\
\text { (Filled) Shelf }\end{array}$ \\
\hline $\begin{array}{l}\text { All libraries } \\
(1400)\end{array}$ & 9.5 & 3.3 & $2.8-31.9$ \\
$\begin{array}{l}5 \text { health sci. } \\
\text { libraries } \\
(1000)\end{array}$ & $(8.7)$ & 3.2 & $2.8-30.5$ \\
$2 \begin{array}{l}\text { science } \\
\text { libraries } \\
(400)\end{array}$ & 9.4 & 3.3 & $2.8-31.9$ \\
\hline
\end{tabular}

*Monograph shelves are overrepresented in these calculations, so that the weighted mean is a more accurate representation. See text.

shelf in the sample and obtains the average of these calculations for each (serials or monograph) sample group. This set of means is shown in tables 3 and 4 in the column "Mean Volumes per Foot of Shelf." The second method finds an "unbiased" average, which is computed by adding up all of the book counts for all of the (serials or monograph) shelves, adding up the total shelf widths occupied by these volumes, and then dividing the two totals to find an "average" VLF for the (serials or monograph) sample group.

The unbiased computations are more appealingly "true" than the shelf-byshelf computations, but do not seem more useful. There is always some shelf capacity loss in any real shelf loading situation regardless of the true width of the books: two 3-foot shelves are filled by either thirty-six 2-inch books or by thirty-four 2.1-inch books although the unbiased VLFs differ. The differences between the two sets of averages is small for this group of samples. The average absolute difference for the fourteen sets is .08 VLF, with the unbiased computation showing a thicker book than the per-shelf statistic in twelve of fourteen cases.

The unbiased averages were adjusted to correct for the different filled-shelf capacities that were discovered after the test data collection had been completed. Inspection showed the adjusted means to be slightly different for two libraries, but not to an extent warranting reentry of the data.

\section{Differences among the Libraries}

It's usually reported that average VLF measures differ not only according to format, but according to the subject content and binding policies of individual libraries.

Data were analyzed to determine whether any significant differences existed between the VLF averages of the seven UC libraries. This was done using the SAS GLM procedure, which carries out Analysis of Variance tests.t In general, these tests inspect a group of different samples to compare the variation found within each of the samples with the variation between the samples. If the variation between the seven VLF averages is much different than the chance variation of the VLF measurements within each library, then there's reason to believe that there may be a significant difference between the libraries with respect to the statistic under inspection.

No significant difference was found between the libraries with respect to their monograph VLF averages. For serials, the averages partition into three different but overlapping groups. The VLF averages for serials at five of the libraries, including the

tA helpful guide was found in R. J. Freund and R. C. Littell, SAS for Linear Models; $a$ Guide to the ANOVA and GLM Procedures (Cary, N.C.: SAS Institute, 1981). 
two science libraries, are not significantly different from each other. Only UCLA's and UCSF's averages differ from the others to any meaningful degree, and only UCLA's average stands by itself. That is, its serials VLF difference from the other libraries is larger than you might expect to occur by chance alone. It is difficult to account for this by subject content, since the broader-than-medical scope of this biomedical library should bring its average "down" to the science libraries average, rather than "up" to a thinner volume. UCLA reports two conditions that may contribute to this finding. The library's automated serials system, in use for about ten years, provides very flexible bindery support and makes it simple to bind in midvolume. Thus the library's policy of providing small bound serials units has been fully supported for some time. UCLA's thinner-than-average serials volumes probably also reflect a 1960 s decision to forgo any multiple-year binding unit, regardless of journal frequency or thickness.

\section{Time Differences between Old and New Material}

We believed there could be a difference in thickness between older and newer books in the stack collections and wished to inspect the samples accordingly. We found that serials at UCSF, UCLA and UCI (Irvine) are shelved in part according to publication date. The date break-off point is different in each case, and excludes History Collection serials at both
UCSF and UCLA, but a large portion of the three samples could be divided into "old" and "new" segments. The averages of the pooled old and new samples from the three libraries are as follows:

$\begin{array}{lccc} & & \text { Mean } & \text { Avg. } \\ \text { Date Group } & n & \text { VLF } & \text { Width/Vol. } \\ \text { "old" serials } & 184 & 7.789 & 1.54 \\ \text { "new" serials } & 114 & 7.912 & 1.52\end{array}$

The expected t-test procedure to inspect the difference between these means proved to be unavailable, and the calculations necessary for a manual test could not be carried out during the project period. However, the width difference is in the expected direction, and further testing of a larger sample may provide useful results.

\section{DISCUSSION \\ How Many Books on a Shelf?}

The monograph findings in this test confirm those of some other recently reported studies and suggest that commonly referenced older medical/scientific books-per-linear-foot measures are not a reliable base for estimating the number of monographs to be found on full stack shelves. Table 5 summarizes some of these results, ${ }^{17-20}$ together with those reported here. Table 5 also indicates that a reliable base for serials, or for combined serials and monograph formats, remains elusive. The 1982 study of serials in the Science Section at the University of Guelph $^{21}$ arrived at a sample serials volume width statistic close to Metcalf's general purpose (solidly filled shelf) periodi-

\section{TABLE 5}

BOOK WIDTH ESTIMATES*

MEDICAL AND SCIENCE LIBRARY COLLECTIONS

\begin{tabular}{lccc}
\hline \hline Source & \multicolumn{3}{c}{ Width in Inches } \\
\hline Metcalf, 1965 & Monographs & Serials & Combined \\
SUNY (3 health sciences libraries), 1977 & $2-2.4$ & $(2.4)+$ & - \\
Univ. of North Carolina Health Science Library, 1980 & 1.1 & - & $1.4-2.0$ \\
Guelph Science Section, 1982 & 1.13 & 2.18 & - \\
Lieberfeld (various surveys) & - & - & 1.33 \\
Univ. of California (5 health sciences libraries), 1983 & $1.05-1.11$ & $1.42-1.73$ & 1.27 \\
Univ. of California (2 science libraries), 1983 & $1.0-1.06$ & $1.64-1.66$ & 1.26 \\
\hline
\end{tabular}

"Calculated from "volumes per linear foot" measures given by Metcalf, SUNY, and in this report; shown as directly reported from Guelph and the Univ. of North Carolina studies.

+Metcalf's "Bound Periodical" statistic, at 5 VLF (2.4-inch width), is the same as his medical book measure, but is not limited by subject. 
cals figure, but a good 26 percent higher than the highest average discovered for serials in this study's samples of UC medical/science libraries. SUNY's related combined-format projections, which err on the side of overestimating width, are immediately between the Guelph and UC figures. ${ }^{22}$ The statistics from Guelph, the University of North Carolina, and UC are all based on sampling rather than on total populations. However, even "worst case" volume widths calculated from the 99 percent confidence intervals for the UC samples remain under those reported earlier (Serials, at UCSD-B: 6.4 VLF, 1.9 inches per volume; Monographs, at UCI: 10.3 VLF, 1.2 inches per volume).

\section{How Many Shelves Do We Need?}

Statistics for solidly filled shelf capacity must be further developed for use in facility planning. The final "optimal" planning statistic is reliable only to the degree that the library's growth rate and the number of years to be planned for are both accurately predicted. Metcalf's commonly cited 86 percent maximum working capacity, ${ }^{23}$ and a standard shelf filing width of $34^{3 / 4}$ inches $(88.3 \mathrm{~cm})$ are used in table 6 to show how different growth rates affect the

TABLE 6

EXAMPLE OF STACK CAPACITY ESTIMATES HYPOTHETICAL STARTING STACK COLLECTION OF 50,000 VOLUMES

\begin{tabular}{lcccc}
\hline $\begin{array}{l}\text { Compounded } \\
\text { Annual } \\
\text { Collection } \\
\text { Growth } \\
\text { Rate* }\end{array}$ & $\begin{array}{c}\text { Vol/LF for } \\
\text { Shelves Filled } \\
\text { Solidly Day 1 } \\
\text { (No. of Shelves) }\end{array}$ & $\begin{array}{c}\text { Vol/LF for } \\
\text { Shelves Filled to } \\
\text { Working Capacity } \\
\text { Day 1 } \\
\text { (No. of Shelves) }\end{array}$ & $\begin{array}{c}\text { Vol/LF for } \\
\text { Shelves with 10 Yr. } \\
\text { Growth Capacity } \\
\text { on Day 1 } \\
\text { (No. of Shelves) }\end{array}$ & $\begin{array}{c}\text { No. of Years Growth } \\
\text { Provided by Metcalf } \\
\text { "Add 50\%" Calculation } \\
\text { (No. of Shelves) }\end{array}$ \\
\hline $\begin{array}{l}3 \text { percent } \\
\text { (e.g., UCSF, }\end{array}$ & 9.5 & 8.2 & 6.1 & 13.7 years \\
$\begin{array}{l}\text { 1972-82) } \\
\begin{array}{l}4.5 \text { percent } \\
\text { (e.g., UCI } \\
\text { Biomed, 1973-82) }\end{array}\end{array}$ & $(1817)$ & $(2106)$ & $(2830)$ & $(3159)$ \\
\hline
\end{tabular}

*This is the average compounded annual growth rate calculated from the volume holdings figure given in the University of California "Size of Libraries" reports for 1972, 1973, and 1982. A common expression for this growth rate is found in the familiar compound interest rate formula: $F V=P V^{*}(1+i)^{n}$, where $F V=$ future amount, $P V=$ present amount, $i=$ interest (i.e., growth) rate, and $n=$ number of periods for which interest (growth) is being calculated. Thus, UCSF's holdings in June 1972 of 370,717 volumes grew to 489,793 volumes in June 1982 at an average annual growth rate (compounded) of roughly 3 percent, as follows:

$489793=(370717)^{*}(1+i)^{10} ; 489793 / 370717=(1+i)^{10} ; 1.32=(1+i)^{10} ; 10 \sqrt{ } 1.32=1+i ; 1.028=1+i ; i=.028$

TABLE 7

PREDICTED VERSUS REPORTED VOLUME HOLDINGS FOR UC LIBRARY COLLECTIONS 1963-1970

\begin{tabular}{lccc}
\hline Campus & $\begin{array}{c}\text { No. of } \\
\text { Years } \\
\text { Projected }\end{array}$ & $\begin{array}{c}\text { Average Annual } \\
\text { Compound Growth } \\
\text { Rate, } \\
\text { Holdings }\end{array}$ & $\begin{array}{c}\text { Average Annual } \\
\text { Compound Growth } \\
\text { Rate, }+ \text { Reported } \\
\text { Holdings }\end{array}$ \\
\hline Berkeley & 7 & .87 & 4.48 \\
Los Angeles & 7 & 6.40 & 6.58 \\
San Francisco & 7 & 4.75 & 6.42 \\
Davis & 7 & 14.62 & 16.54 \\
Riverside & 7 & 13.65 & 18.76 \\
Santa Barbara & 7 & 16.00 & 18.01 \\
San Diego & 7 & 19.94 & 30.26 \\
Irvine & 5 & 26.40 & 31.25 \\
Santa Cruz & 5 & 24.57 & 31.12 \\
\hline
\end{tabular}

"Calculated from "Projected Volume Holdings . . . Fall Semester" of 1963 (or 1965) and 1970, given in University of California, Budget for Capital Outlay, 1964-65 and Five-Year Major Capital Improvement Program, 1964-69 (Berkeley: University of California, 1963).

tCalculated from "Bound Volumes" holdings for 1963 or 1965 and 1970, given in Table I of "Size of the Libraries of the University of California on 30 June..." published as attachments to CU News 1963, 1965, and 1970. Figures for 1970 are shown as corrected in 1971 for Berkeley and Los Angeles. 
VLF measures applicable to a hypothetical collection.

Table 7 shows the results of comparing UC's 1964 growth forecasts with the afterthe-fact growth rates given in the university's "Size of Library" reports. The projected growths were frequently far off the mark, despite the short projection periods, and underscore the fact that the problem of arriving at useful shelf capacity planning figures is only peripherally related to the problem of estimating how many books fit on a shelf.

An added prediction problem was found to result from the use of area space standards that assume a fixed number of shelves in a stack section. More than one quarter of the monograph and more than 10 percent of the serials stack sections in this study had fewer than seven shelves, a loss of 1,495 shelves and nearly 4,500 linear feet assumed to be available to this group of libraries. Planners obviously cannot predict future constraints of site and design, but appropriate early modification of opening capacity estimates appears necessary to an effective ongoing planning process.

Means for reliable growth-rate prediction were outside the scope of this study, but the width estimate remains a necessary base for planning calculations and was found in this preliminary study to vary greatly according to format. Thus the relative format emphasis of collections, as well as their subject content, appears to merit continued discrimination and attention.

\section{REFERENCES}

1. Keyes D. Metcalf, Planning Academic and Research Library Buildings (New York: McGraw-Hill, 1965), p.153.

2. Joseph L. Wheeler and Alfred Morton Githens, The American Public Library Building: Its Planning and Design with Special Reference to Its Administration and Service (Chicago: American Library Assn., 1941), p.415.

3. Metcalf, Planning, p.153.

4. American Library Association, Library Administration Division, Ad Hoc Committee on the Physical Facilities of Libraries, Section on Library Organization and Management, Measurement and Comparison of Physical Facilities for Libraries (Chicago: ALA, 1970).

5. P. N. Kaula, "Capacity of the Stacks in a Technical Library," Herald of Library Science 7:131-34 (Apr. 1968).

6. Frazer G. Poole, "The Selection and Evaluation of Library Bookstacks," Library Trends 13:419 (Apr. 1965), p.419.

7. Gayle E. Evans and others, Library Environmental Design: Physical Facilities and Equipment (Los Angeles: University of California Institute of Library Research, 1971), p.131.

8. Lucille J. Strauss, Irene M. Shreve, and Alberta L. Brown, Scientific and Technical Libraries: Their Organization and Administration, 2d ed. (New York: Becker and Hayes, 1972), p.70.

9. Estey Corporation, Library Shelving (Red Bank, N.J.: The Corporation, 1978).

10. William J. Hubbard, Stack Management (Chicago: ALA, 1981), p.41-42.

11. Martha Jane K. Zachert, Standards and Planning Guide for Pharmacy Service (Bethesda, Md.: American Association of Colleges of Pharmacy, 1975), p.15.

12. U.S. Public Health Service, Medical Education Facilities: Planning Considerations and Architectural Guide, PHS Publication no.1180-A-1 (Washington: Public Health Service, 1964).

13. Alderson Fry, "Library Planning, Furniture, and Equipment," in Handbook of Medical Library Practice, 3d ed., eds. Gertrude Annan and Jacqueline Felter. (Chicago: Medical Library Association, 1970), p.305.

14. Linda L. Brogan and Carolyn E. Lipscomb, "Moving the Collections of an Academic Health Sciences Library," Bulletin of the Medical Library Association 70:377 (Oct. 1982).

15. Ralph M. Daehn, Space for Growth; the Measurement and Projection of Shelf Space at the University of Guelph Library (Guelph: University of Guelph Library, 1982), p.11.

16. Wheeler, American Public Library Building, p.414-15.

17. Brogan, "Moving the Collections," p.377.

18. Daehn, Space, p.11.

19. Karen Wittenborg and John F. Camp, Shelf Space Projection Survey (n.p.: SUNY Council of Head 
Librarians, 1977), p.6,12. "We calculated the [library's] average number of volumes per linear foot . . . by dividing its collection size by the number of its filled or partially filled shelves." (These projections err in the direction of overestimating book width).

20. Lawrence Lieberfeld, "The Curious Case of the Library Building," College \& Research Libraries 44:279 (July 1983).

21. Daehn, Space, p.11.

22. Wittenborg, Shelf Space Survey, p.12.

23. Metcalf, Planning, p.155.

\section{Midwest Library Service}

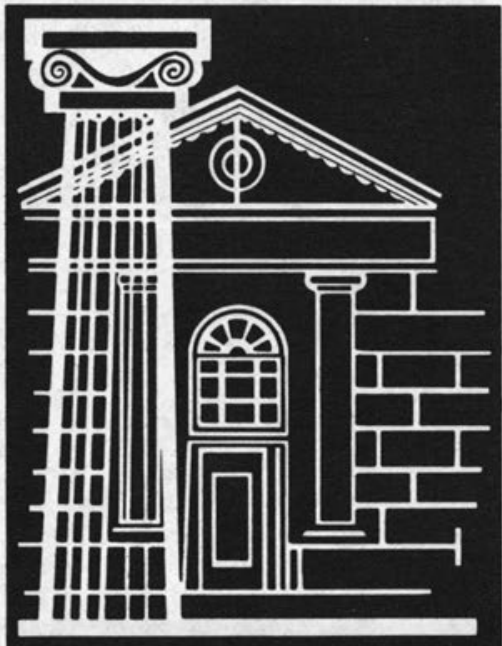

\section{You won't find more specialized service ... anywhere}

College and university librarians: If there are gaps in services being rendered by your current library jobber, then Midwest Library Service may be what you're looking for. Midwest has specialized in service to college and university libraries for 24 years-so long that providing books from even the most obscure publisher is standard practice. For prompt, efficient service on all orders, contact Midwest Library Service.

\section{Midwest Library Service \\ 11443 St. Charles Rock Road Bridgeton, MO 63044}

Call toll-free $(800) 325-8833$

Missouri librarians call toll-free (800) 392-5024 Canadian librarians call collect (314) 739-3100 


\section{Why search the Federal Register page-by-page?}

\begin{tabular}{|c|c|c|}
\hline $\begin{array}{c}\text { Check for regulations } \\
\text { with one look-up }\end{array}$ & $\begin{array}{c}\text { Find proposed rules } \\
\text { and notices in seconds }\end{array}$ & $\begin{array}{c}\text { Monitor the latest } \\
\text { federal } \\
\text { announcements }\end{array}$
\end{tabular}

Now there's a faster, more reliable way to keep posted on federal announcements, rule changes, and deadlines...the CIS Federal Register Index (FRI).

\section{Save time}

With FRI you can hone in on exactly the information you need-in seconds. Just look under a common-sense subject heading that describes your interests. There you'll find a descriptive notation on each relevant new item in the Register.

\section{Find deadlines at a glance}

FRI's "calendar" section gives you an easy-toscan rundown of all the upcoming comment deadlines, reply deadlines, hearing dates, and effective dates. It's a convenient checklist to assure you don't overlook important opportunities-or dangers.

\section{Get currency plus convenience}

FRI is published weekly, so you'll have time to act before deadlines expire. Plus you get regular cumulations, so you have fewer look-ups when searching for items that appeared in past issues of the Register.

\section{Introducing the new weekly CIS FEDERAL REGISTER IVDEX}

Call for a free issue

Find out what this innovative-yet economical-new service can do for you. Call our toll-free number for a free sample issue. Or fill in and mail the coupon below. There is no cost or obligation whatsoever. or $301-654-1550$ 

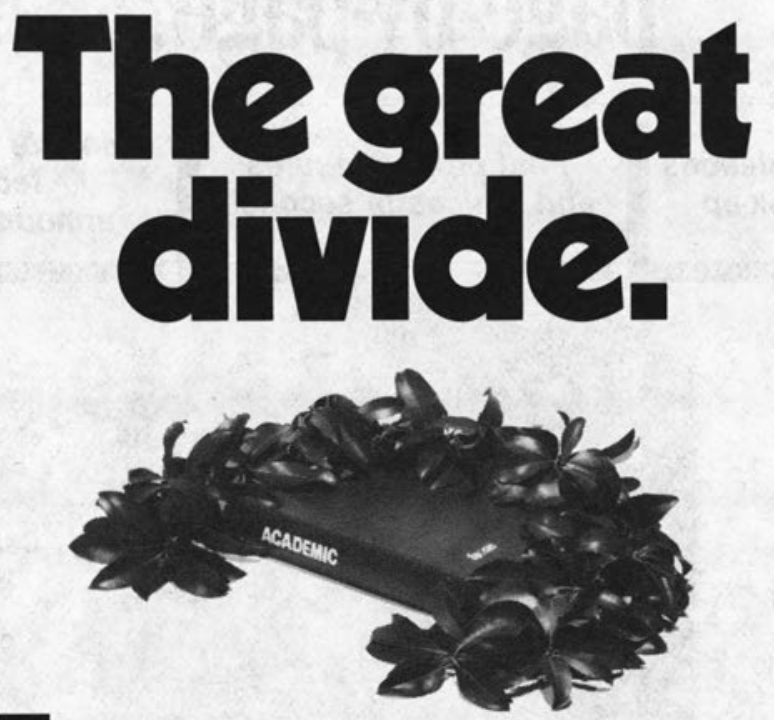

axon's new Academic Division rewards you with better service. You now get the individual attention of someone familiar with your needs along with access to the vast resources commanded by Faxon.

More than 100 years of dedicated service to libraries have put Faxon at the forefront of the information frontier. We were the first agency to completely automate subscription management. First to develop an international online network. First to establish online links with major publishers.

We'll give you an edge on tomorrow. A frontier we conquer by not resting on our laurels.

$800225 \cdot 6055$

or $617329-3350$

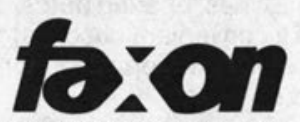

ON THE FRONTIER OF INFORMATION MANAGEMENT

The Faxon Company, Inc. 15 Southwest Park Westwood, MA 02090 